\title{
The Comparative PDT Experiment of the Inactivation of HL60 on Modified $\mathrm{TiO}_{2}$ Nanoparticles
}

\author{
Kaiqi Lu, ${ }^{1}$ Qiyun He, ${ }^{1}$ Li Chen, ${ }^{2}$ Baoquan $A i,{ }^{1}$ and Jianwen Xiong ${ }^{1}$ \\ ${ }^{1}$ Laboratory of Quantum Information Technology, School of Physics and Telecommunication Engineering, \\ South China Normal University, Guangzhou 510006, China \\ ${ }^{2}$ School of Physics and Optoelectronic Engineering, Guangdong University of Technology, Guangzhou 510006, China
}

Correspondence should be addressed to Jianwen Xiong; jwxiong@scnu.edu.cn

Received 24 February 2015; Revised 24 May 2015; Accepted 10 June 2015

Academic Editor: Paulo Cesar Morais

Copyright (C) 2015 Kaiqi Lu et al. This is an open access article distributed under the Creative Commons Attribution License, which permits unrestricted use, distribution, and reproduction in any medium, provided the original work is properly cited.

\begin{abstract}
Four samples of modified titanium dioxide $\left(\mathrm{TiO}_{2}\right), \mathrm{Fe} / \mathrm{TiO}_{2}(2 \mathrm{wt} \%), \mathrm{Fe} / \mathrm{TiO}_{2}$ (5 wt\%), and 5-ALA/TiO ${ }_{2}$, were experimented in photodynamic therapy (PDT) on leukemia cells HL60, performing promising photocatalytic inactivation effect. $\mathrm{Fe} / \mathrm{TiO}_{2}$ and 5$\mathrm{ALA} / \mathrm{TiO}_{2}$ were synthesized in methods of precipitation and ultrasonic methods, respectively. X-ray diffraction spectra and UV-Vis spectra were studied for the samples' crystalline phase and redshift of absorption peak. Further, FTIR spectra and Raman spectra were obtained to examine the combination of 5-aminolevulinic (5-ALA) and $\mathrm{TiO}_{2}$ nanoparticles. The toxicity of these four kinds of nanoparticles was studied through darkroom experiments. And based on the concentration which caused the same toxic effect (90\%) on HL60, PDT experiments of $\mathrm{TiO}_{2}, \mathrm{Fe} / \mathrm{TiO}_{2}(2 \%), \mathrm{Fe} / \mathrm{TiO}_{2}(5 \%)$, and $\mathrm{ALA} / \mathrm{TiO}_{2}$ were done, resulting in the fact that the photokilling efficiency was $69.7 \%, 71.6 \%, 72 \%$, and $80.6 \%$, respectively. Scanning electron microscope (SEM) images of the samples were also taken to study the morphology of HL60 cells before and after PDT, resulting in the fact the activation of the modified $\mathrm{TiO}_{2}$ from PDT was the main cause of cell apoptosis.
\end{abstract}

\section{Introduction}

Titanium dioxide $\left(\mathrm{TiO}_{2}\right)$ has been widely used in biomedical, industrial, environmental, and energy technology fields during the past two decades on account of its chemical and physical property [1]. For instance, iron and chromium doped $\mathrm{TiO}_{2}$ nanotube had a promising effect on the degradation of environmental and industrial pollutants [2]. $\mathrm{Ag} / \mathrm{TiO}_{2}$ nanoparticles showed great photocatalytic effect on the degradation of water pollutions [3]. Wang and his team pointed out that $\mathrm{TiO}_{2}$ based photocatalytic process for purification of polluted water had bridged fundamentals to applications [4]. It has been proven that pairs of photo-induced electrons and holes generated on the surface of $\mathrm{TiO}_{2}$ under the irradiation of ultraviolet (UV) light $[5,6]$ performed strong reduction and oxidation power and could react with hydroxyl ions and water to form various reactive oxygen species (ROS) which played an important role in photodynamic therapy (PDT) [7-9].

In spite of its tremendous effect on killing cancer cells, the application of $\mathrm{TiO}_{2}$ in $\mathrm{PDT}$ was hindered by a few of its properties. $\mathrm{TiO}_{2}$, with the band gap of $3.23 \mathrm{eV}$ for anatase, turned excited only when exposed to UV light; furthermore, the activated electron-hole pairs had a high speed rate of recombination, which would weaken the promising photocatalytic effect in PDT $[10,11]$. Seeing its potential practical use, a wealth of researches had been done on the method of modification to enhance the efficiency of $\mathrm{TiO}_{2}$ treatments on cancer cells and received sound results. $\mathrm{Pt}-\mathrm{TiO}_{2}$ has been demonstrated effective in treatment of localized tumors [12]. $\mathrm{ZnPc}-\mathrm{TiO}_{2}$ has been proved an excellent candidate as sensitizer in PDT against cancer and infectious diseases [13]. Water-dispersed $\mathrm{TiO}_{2}$-polyethylene glycol compound had high antitumor effect in PDT [14]. Other modified $\mathrm{TiO}_{2}$ nanoparticles such as $\mathrm{N}-\mathrm{TiO}_{2}, \mathrm{Er}^{3+}-\mathrm{Yb}^{3+}-\mathrm{Fe}^{3+}$ tridoped $\mathrm{TiO}_{2}$, and $\mathrm{Au} / \mathrm{TiO}_{2}$ had been proved to have higher photocatalytic effect than pure $\mathrm{TiO}_{2}$ on tumor cell [15-18]. Our laboratory had made some progress on tests of in vitro PDT based on modified $\mathrm{TiO}_{2}$ such as $\mathrm{CdS}$ doped $\mathrm{TiO}_{2}, \mathrm{Fe}-\mathrm{N}$ codoped $\mathrm{TiO}_{2}$, and $\mathrm{TiO}_{2}-\mathrm{xNx}[19,20]$. 
In this paper, four kinds of nanoparticles (including $\mathrm{TiO}_{2}$, $\mathrm{Fe} / \mathrm{TiO}_{2}$ (2 $\left.\mathrm{wt} \%\right), \mathrm{Fe} / \mathrm{TiO}_{2}\left(5 \mathrm{wt} \%\right.$ ), and $5-\mathrm{ALA} / \mathrm{TiO}_{2}$ ) were applied in PDT experiments on leukemic HL60 cells. Each dose was used and tested separately for PDT and toxicity experiments, and the comparison of cell viability between each independent experiment has been specifically studied, and this possible use of the experimental nanoparticles will be discussed at the end of this paper.

\section{Materials and Methods}

2.1. Chemicals and Apparatus. HL60 cells were kindly provided by the Department of Medicine of Sun Yat-sen University. 5-aminolevulinic acid (ALA) was purchased from Shanghai Xianhui Pharmaceutical Co. Ltd. (CHN). $\mathrm{TiO}_{2}$ nanoparticles were purchased from Degussa (GER). RPMI medium 1640 was obtained from Gibco BRL (USA). Cell Counting Kit-8 (CCK-8) assays were purchased from Dojindo (Japan). $\mathrm{Fe} / \mathrm{TiO}_{2}(2 \%)$ and $\mathrm{Fe} / \mathrm{TiO}_{2}(5 \%)$ nanoparticles were synthesized in the method of precipitation by Department of Physics and Electronic Engineering of South China Normal University. 5-ALA/ $\mathrm{TiO}_{2}$ nanoparticles were synthesized by author's laboratory. All chemicals were of the highest purity commercially available. The tock solutions were well prepared in serum-free medium before use and materials stored in sealing space at a proper temperature.

The apparatus used included UV-2550 UV-visible spectrophotometer (Hitachi, Japan), HH.CP-TW80 CO $\mathrm{CO}_{2}$ Incubator, DG5031 ELISA Reader (Nanjing Huadong Electronics Group Medical Equipment Co., Ltd., China), BS124S Electronic Scales (Sartorius, GER), SK2510LHC Ultrasonic Cleaner (KUDOS, China), SW-CJ Standard Clean Bench (Suzhou Antai Airtech Co., Ltd., China), LPE-1A Laser Power Meter (Physcience Opto-Electronics, Beijing), Eppendof (Finland), lab-assembled PDT light reaction chamber, 96well culture plates, cell counting boards, and so on.

2.2. Cell Culture. Leukemia HL60 cells were cultured in RPMI 1640 medium with 10\% fetal bovine serum (FBS) and refreshed daily. They were stored in a humidified incubator with $5 \% \mathrm{CO}_{2}$ at $37^{\circ} \mathrm{C}$ before use. In order to maximum the reliability of PDT effect, cells viability will be measured using a countess automated cell counter, verifying their sound concentration over $95 \%$.

\subsection{Preparation of Modified $\mathrm{TiO}_{2}$ Nanoparticles}

2.3.1. Synthesis of $5-A L A / \mathrm{TiO}_{2}$. 5-ALA/TiO 2 nanoparticles were synthesized in a way of surface modification. $2.62 \mathrm{mg}$ 5-ALA and $3.2 \mathrm{mg} \mathrm{TiO}_{2}$ nanoparticles were measured by an electronic scale and then dissolved in $20 \mathrm{~mL}$ deionized water contained with a beaker. Subsequently, the beaker was then sealed, vibrated using a magnetic stirrer, and placed in ultrasonic heater for an ultrasonic processing of $4 \mathrm{~h}$. In this process, carboxyl groups on 5-ALA were believed to bond with the hydrogen bonds on $\mathrm{TiO}_{2}$ nanoparticles. In this way, the 5-ALA/ $\mathrm{TiO}_{2}$ nanoparticles with a molar mass ratio (5$\mathrm{ALA}: \mathrm{TiO}_{2}$ ) of $2: 1$ were synthesized.
2.3.2. Synthesis of $\mathrm{Fe} / \mathrm{TiO}_{2} . \mathrm{Ti}\left(\mathrm{SO}_{4}\right)_{2}, \mathrm{C}_{18} \mathrm{H}_{29} \mathrm{NaO}_{3} \mathrm{~S}$ (DBS), $\mathrm{H}_{2} \mathrm{NCONH}_{2}$, deionized water, $\mathrm{CH}_{3} \mathrm{CH}_{2} \mathrm{OH}$, and concentrated $\mathrm{H}_{2} \mathrm{SO}_{4}$ were compounded together in doses of $6 \mathrm{~g}$, $0.18 \mathrm{~g}, 32 \mathrm{~g}, 250 \mathrm{~mL}, 0.25 \mathrm{~mL}$, and $0.25 \mathrm{~mL}$, respectively, with a certain dose of $\mathrm{Fe}_{2}\left(\mathrm{SO}_{4}\right)_{3} ; 0.1 \mathrm{~g} \mathrm{Fe}_{2}\left(\mathrm{SO}_{4}\right)_{3}$ was applied to obtain $\mathrm{Fe} / \mathrm{TiO}_{2}(2 \%)$ and $0.5 \mathrm{~g}$ to $\mathrm{Fe} / \mathrm{TiO}_{2}(5 \%)$. The beaker of the reactant was put in $80^{\circ} \mathrm{C}$ thermostatic bath, quickly stirred for 2 to 3 hours until the $\mathrm{PH}$ value of the reactant reached 2. Then another 24 hours were taken for its complete sedimentation. Subsequently, $\mathrm{SO}_{4}{ }^{2-}$ and the activator on the surface of DBS were washed away using deionized water until there was no $\mathrm{BaSO}_{4}$ produced when $\mathrm{BaCl}_{2}$ solution was tentatively added. $\mathrm{CH}_{3} \mathrm{CH}_{2} \mathrm{OH}$ was added to dehydrate the sample. After 3-hour desiccation in drying oven, our sample was grinded for 15 minutes in an automatic desktop grinder and then sintered for 30 minutes in a high temperature electric furnace at $450^{\circ} \mathrm{C}$. When the sample cooled down, it was grinded again for 15 minutes and collected for use. The involved chemical equations were listed below:

$$
\begin{aligned}
& \mathrm{Ti}\left(\mathrm{SO}_{4}\right)_{2}+\mathrm{H}_{2} \mathrm{O} \longrightarrow \mathrm{TiOSO}_{4}+\mathrm{H}_{2} \mathrm{TiSO}_{3} \downarrow \\
& \mathrm{CO}\left(\mathrm{NH}_{2}\right)_{2}+3 \mathrm{H}_{2} \mathrm{O} \longrightarrow 2 \mathrm{NH}_{4}^{+}+2 \mathrm{OH}^{-}+\mathrm{CO}_{2} \uparrow \\
& \mathrm{Ti}^{4+}+2 \mathrm{OH}^{-} \longrightarrow \mathrm{Ti}(\mathrm{OH})_{4} \downarrow \\
& \mathrm{TiO}^{2+}+2 \mathrm{OH}^{-} \longrightarrow \mathrm{TiO}(\mathrm{OH})_{2} \downarrow \\
& \text { (1) } \mathrm{H}_{2} \mathrm{TiSO}_{3} \longrightarrow \mathrm{TiO}_{2}+\mathrm{H}_{2} \mathrm{O} \\
& \text { (2) } \mathrm{Ti}(\mathrm{OH})_{4} \longrightarrow \mathrm{TiO}_{2}+2 \mathrm{H}_{2} \mathrm{O} \\
& \text { (3) } \mathrm{TiO}(\mathrm{OH})_{2} \longrightarrow \mathrm{TiO}_{2}+\mathrm{H}_{2} \mathrm{O} \\
& \mathrm{Fe}^{3+}+\mathrm{OH}^{-} \longrightarrow \mathrm{Fe}(\mathrm{OH})_{3} \downarrow \\
& 2 \mathrm{Fe}(\mathrm{OH})_{3} \longrightarrow \mathrm{Fe}_{2} \mathrm{O}_{3}+3 \mathrm{H}_{2} \mathrm{O}
\end{aligned}
$$

2.4. CCK-8 Assay. Cell viability of the samples was evaluated by Cell Counting Kit- 8 assays (CCK- 8 assay) [21]. Cell suspension was seeded into 96-well plate. Each well contained $200 \mu \mathrm{L}$ HL60 cell suspension and $20 \mu \mathrm{L}$ CCK-8 solution. The 96 -well plates then were placed in an incubator $\left(37^{\circ} \mathrm{C} 5 \%\right.$ $\mathrm{CO}_{2}$ ) for 4 hours before the samples' OD value at $490 \mathrm{~nm}$ was determined by the Model 680 Microplate Reader. In order to guarantee the accuracy, each sample was seeded into 3 wells to obtain a mean value. The cell viability was calculated by comparison with the OD value of untreated cells.

2.5. Scanning Electron Microscope. Samples of treated HL60 cells were fixed in $2.5 \%$ glutaraldehyde in $0.1 \mathrm{M}$ phosphate buffer solution (PBS) and freeze-dried in $6^{\circ} \mathrm{C}$ for 6 hours. Then they were washed three times by $0.1 \mathrm{M}$ phosphate buffer solution and dehydrated by ethanol solution of $30 \%, 50 \%$, $70 \%, 90 \%$, and $100 \%$ successively. Isoamyl acetate was used to replace the ethanol solution in cell samples and subsequently removed by $\mathrm{CO}_{2}$ in critical point drying method. Finally, the samples were coated with platinum in automatic high vacuum coating system (QuorumQ150T ES) before observation in a ZEISS Ultra-55 scanning electron microscope. 


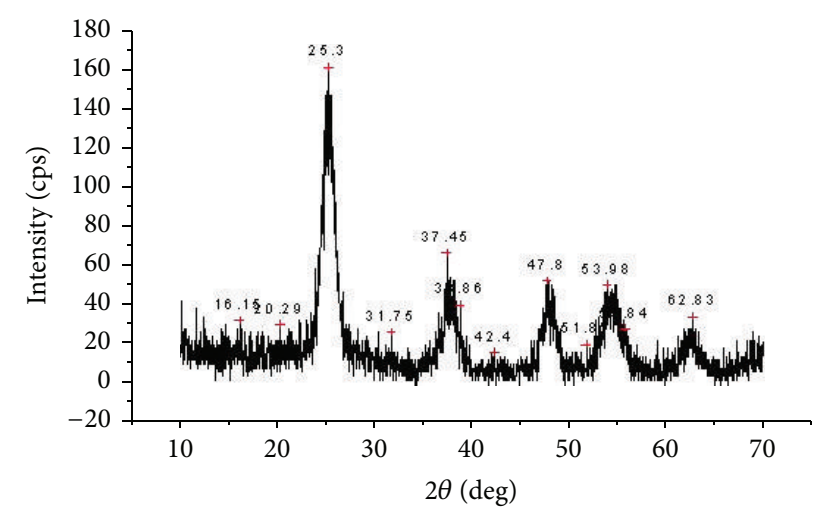

(a)

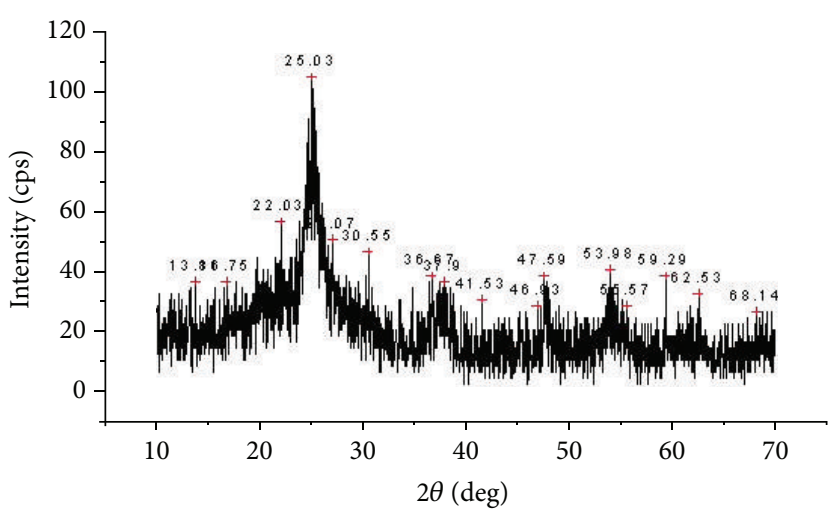

(b)

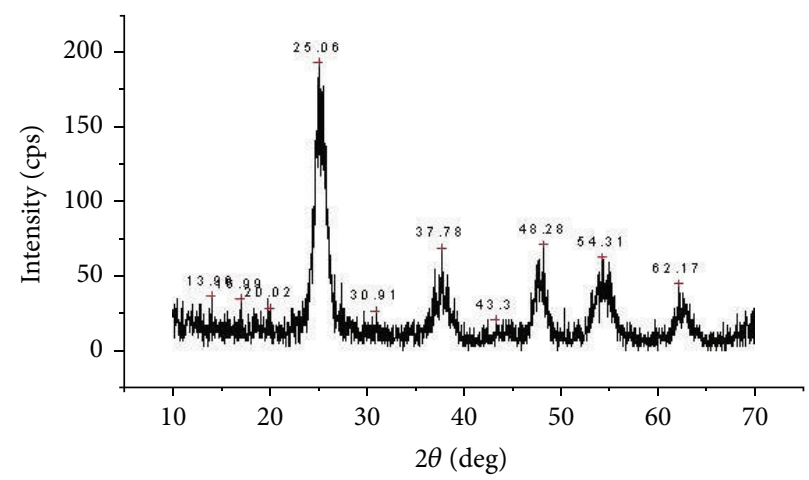

(c)

FIGURE 1: X-ray diffraction of nanoparticles: (a) pure $\mathrm{TiO}_{2}$ nanoparticles used to synthesize 5-ALA/TiO $;$; (b) Fe/TiO 2 (2\%) nanoparticles; (c) $\mathrm{Fe} / \mathrm{TiO}_{2}(5 \%)$ nanoparticles.

2.6. Statistical Analysis. Data are presented as means $\pm \mathrm{SD}$ (standard deviation) from three independent groups. Statistical software SPSS11.5 is used in statistical analysis. Any data with value $P$ smaller than 0.05 are considered statistically significant.

\section{Results and Discussion}

\subsection{Characterization of $5-\mathrm{ALA} / \mathrm{TiO}_{2}, \mathrm{Fe} / \mathrm{TiO}_{2}$ Nanoparticles}

3.1.1. X-Ray Diffraction Spectra. X-Ray diffraction is a solid method in analyzing crystalline structural properties. Thus, $\mathrm{XRD}$ images were taken to investigate the crystalline phases of three samples, pure $\mathrm{TiO}_{2}$ used for the synthesis of 5$\mathrm{ALA} / \mathrm{TiO}_{2}, \mathrm{Fe} / \mathrm{TiO}_{2}$ (2\%), and $\mathrm{Fe} / \mathrm{TiO}_{2}$ (5\%); they were presented in Figures 1(a), 1(b), and 1(c), respectively. Characteristic peaks in accordance with crystalline phases of (101) were found in all of the samples. Also there was no characteristic peak in (110) $2 \theta=27.4^{\circ}$, indicating that the samples are primarily in anatase phase. $\mathrm{TiO}_{2}$ had three basic crystal phases, anatase, rutile, and brookite. It has been demonstrated that the anatase phase $\mathrm{TiO}_{2}$ showed highest photocatalytic efficiency among the three $[22,23]$. By comparison, characteristic peaks in Figure 1(b) were less crystallized; but the ones in Figures 1(a) and 1(c) were observed sharper, indicating that $\mathrm{TiO}_{2}$ and $\mathrm{Fe} / \mathrm{TiO}_{2}$ (5\%) were more crystallized than $\mathrm{Fe} / \mathrm{TiO}_{2}(2 \%)$.

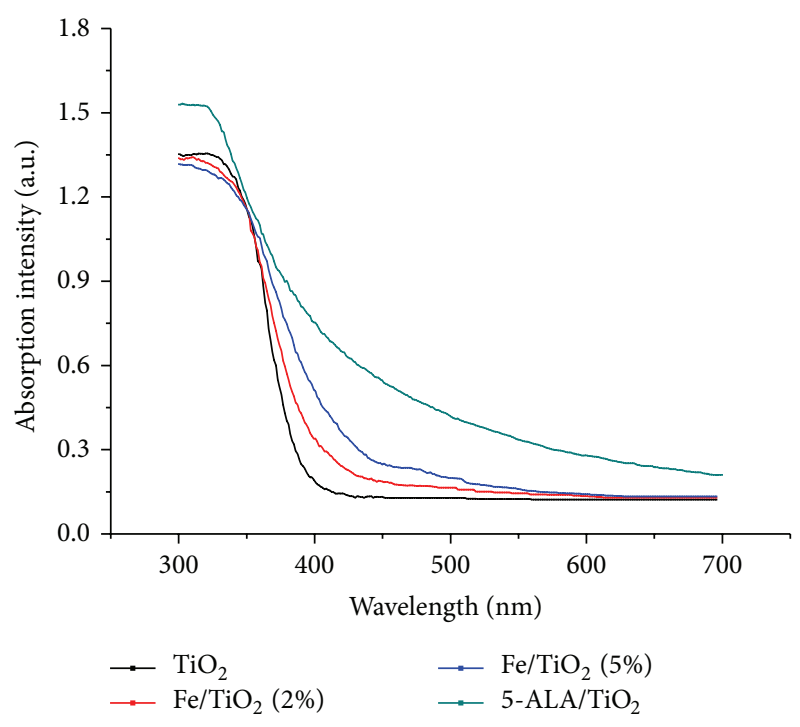

Figure 2: UV-Vis spectra of $\mathrm{TiO}_{2}, 5-\mathrm{ALA} / \mathrm{TiO}_{2}, \mathrm{Fe} / \mathrm{TiO}_{2}(2 \%)$, and $\mathrm{Fe} / \mathrm{TiO}_{2}(5 \%)$ nanoparticles.

3.1.2. UV-Vis Spectra. UV-Vis spectra of the nanoparticles were studied to investigate their photocatalytic performance. As is shown in Figure 2, the spectrum of $\mathrm{TiO}_{2}$ has a very sharp 


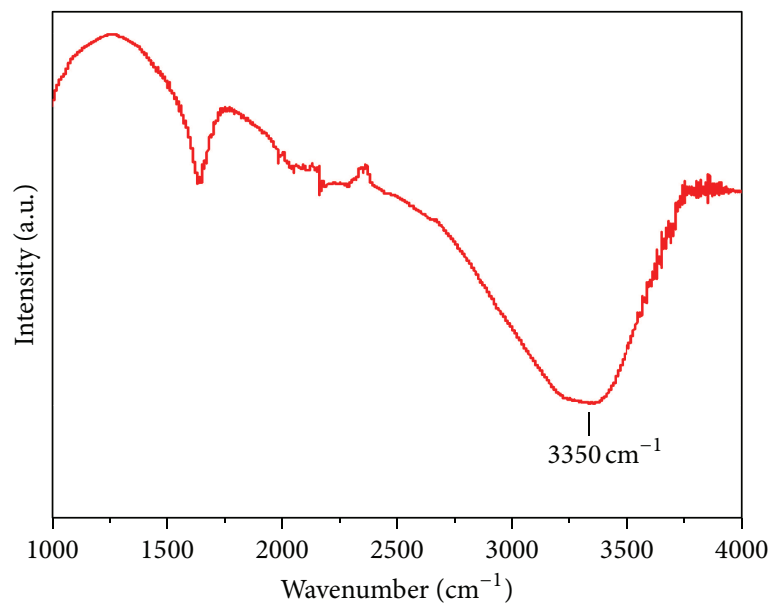

(a)

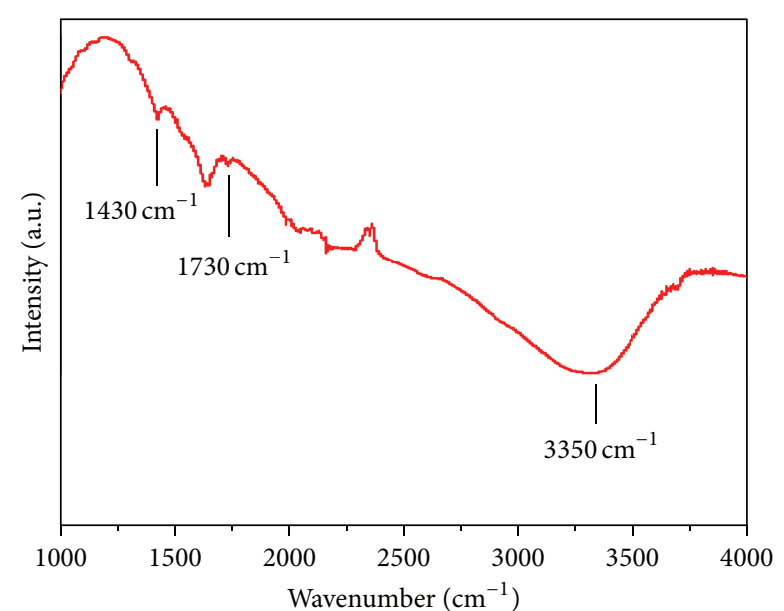

(b)

FIgURE 3: FTIR spectra: (a) $\mathrm{TiO}_{2}$ nanoparticles; (b) 5-ALA/ $\mathrm{TiO}_{2}$ nanoparticles.

edge from 350 to $400 \mathrm{~nm}$, presenting that $\mathrm{TiO}_{2}$ nanoparticles absorb light primarily from ultraviolet region. UV-Vis spectra of $5-\mathrm{ALA} / \mathrm{TiO}{ }_{2}, \mathrm{Fe} / \mathrm{TiO}_{2}(2 \%)$, and $\mathrm{Fe} / \mathrm{TiO}_{2}(5 \%)$ were also observed; by comparison, we observed varying degrees of redshift, indicating that the light absorption of $\mathrm{TiO}_{2}$ has been enhanced and expanded to visible light region, meaning that damage on normal cells from UV light during clinical treatments could be reduced. $\mathrm{TiO}_{2}$ with a higher concentration of $\mathrm{Fe}$ ions absorbed more visible light. We also observed that the redshift of 5-ALA/ $/ \mathrm{TiO}_{2}$ was more obvious than the former; the absorption of visible light was largely promoted. Our result demonstrated that the modification of $\mathrm{TiO}_{2}$ nanoparticles, especially with 5-ALA, helps enhance the visible light absorption. This phenomenon of redshift allowed photocatalytic activity of $\mathrm{TiO}_{2}$ to be further activated by visible light irradiation.

3.1.3. FTIR Spectra of $\mathrm{TiO}_{2}$ and $5-A L A / \mathrm{TiO}_{2}$. As shown in Figures 3(a) and 3(b), the FTIR spectra of $\mathrm{TiO}_{2}$ and 5$\mathrm{ALA} / \mathrm{TiO}_{2}$ were studied to characterize the modification of 5-ALA $/ \mathrm{TiO}_{2}$ nanoparticles. Characteristic peak of hydroxyl on surface of $\mathrm{TiO}_{2}$ and 5-ALA/TiO ${ }_{2}$ nanoparticles emerged in $3350 \mathrm{~cm}^{-1}$. Further, characteristic peaks of carboxylic ester (-COOTi-) emerged in $1430 \mathrm{~cm}^{-1}$ and $1730 \mathrm{~cm}^{-1}$ in Figure $3(\mathrm{~b})$. This finding illustrated that possible reaction, similar to the esters produced by chemical reactions of carboxylic acids and alcohols, might happen between 5-ALA and $\mathrm{TiO}_{2}$. The weakening of peak $3350 \mathrm{~cm}^{-1}$ in Figure 3(b) demonstrated again that the potential reaction consumed part of the hydroxyl. The potential chemical equation was presented as follows:

$$
\begin{aligned}
& \mathrm{TiO}_{2}(\mathrm{OH}) n+y \mathrm{HOOC}_{5} \mathrm{H}_{8} \mathrm{NO}-\mathrm{TiO}_{2}(\mathrm{OH}) n \\
& -y\left(\mathrm{OOC}_{5} \mathrm{H}_{8} \mathrm{NO}\right) y+y \mathrm{H}_{2} \mathrm{O}
\end{aligned}
$$

3.1.4. Raman Spectrum of 5-ALA/TiO . Raman spectrum of $5-\mathrm{ALA} / \mathrm{TiO}_{2}$ was also taken to reaffirm the existence of

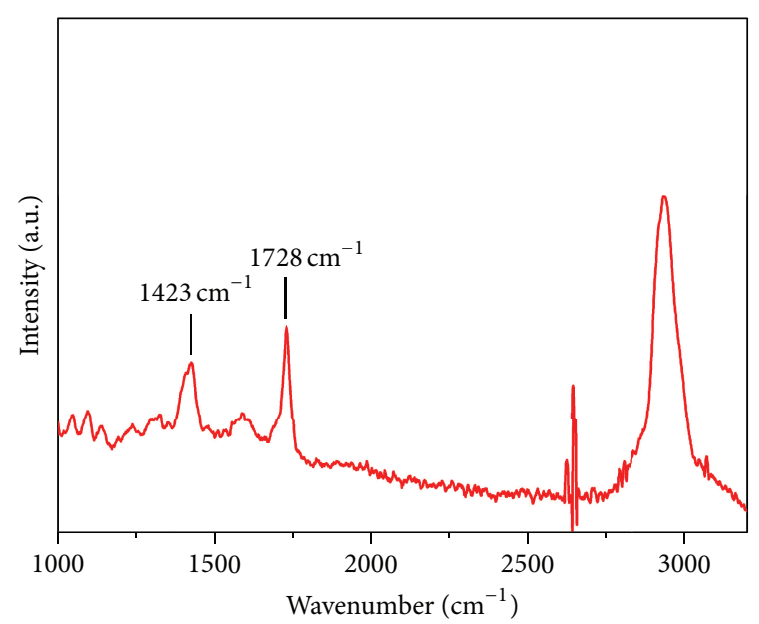

FIGURE 4: Raman spectrum of 5-ALA/TiO 2 nanoparticles.

carboxylic ester (-COOTi-). As shown in Figure 4, characteristic peaks of carboxylic ester could be observed more clearly in $1423 \mathrm{~cm}^{-1}$ and $1728 \mathrm{~cm}^{-1}$, which matched the finding from the FTIR spectra in Section 3.1.3.

3.2. Cytotoxicity of Modified $\mathrm{TiO}_{2}$ Nanoparticles on HL60. Low dark toxicity is known as one of the important features of photosensitive drugs. We ran a series of experiments to test the dark toxicity of our modified $\mathrm{TiO}_{2}$ nanoparticles on HL60 cells. Various concentrations $(0 \mu \mathrm{g} / \mathrm{mL}$, $50 \mu \mathrm{g} / \mathrm{mL}, 100 \mu \mathrm{g} / \mathrm{mL}, 150 \mu \mathrm{g} / \mathrm{mL}, 200 \mu \mathrm{g} / \mathrm{mL}, 250 \mu \mathrm{g} / \mathrm{mL}$, $500 \mu \mathrm{g} / \mathrm{mL}$, and $1000 \mu \mathrm{g} / \mathrm{mL}$ ) of $\mathrm{TiO}_{2}, \mathrm{Fe} / \mathrm{TiO}_{2}(2 \%), \mathrm{Fe} / \mathrm{TiO}_{2}$ $(5 \%)$, and that $(72.75 \mu \mathrm{g} / \mathrm{mL}, 145.50 \mu \mathrm{g} / \mathrm{mL}, 218.25 \mu \mathrm{g} / \mathrm{mL}$, $291.00 \mu \mathrm{g} / \mathrm{mL}, 363.75 \mu \mathrm{g} / \mathrm{mL}, 436.50 \mu \mathrm{g} / \mathrm{mL}, 582.00 \mu \mathrm{g} / \mathrm{mL}$, and $1164.00 \mu \mathrm{g} / \mathrm{mL}$ ) of $5-\mathrm{ALA} / \mathrm{TiO}_{2}$ were adopted in the test; the OD value of HL60 was measured after culturing for 48 hours, and the relative cell viability of HL60 was presented in Figure 5. 


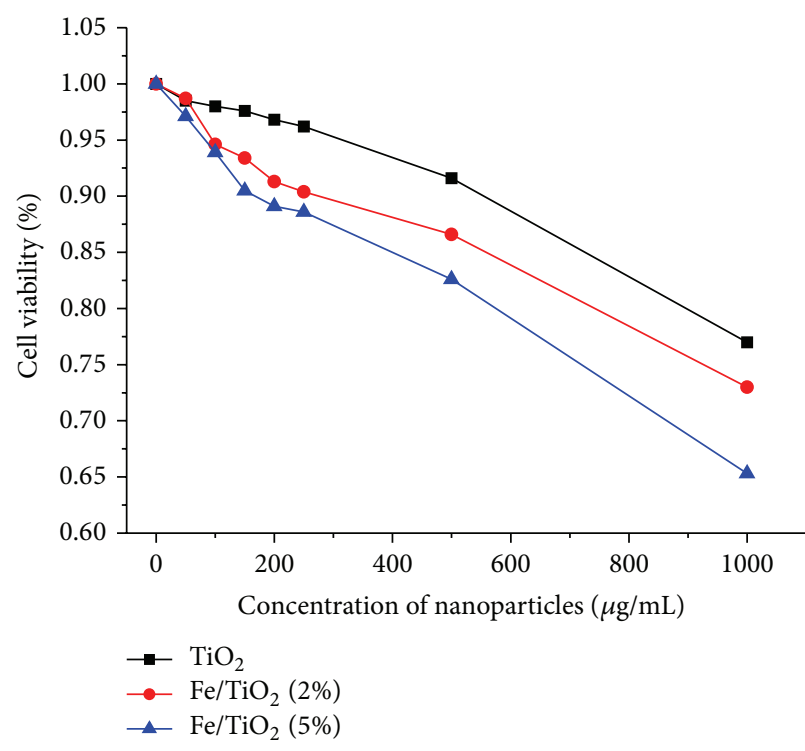

(a)

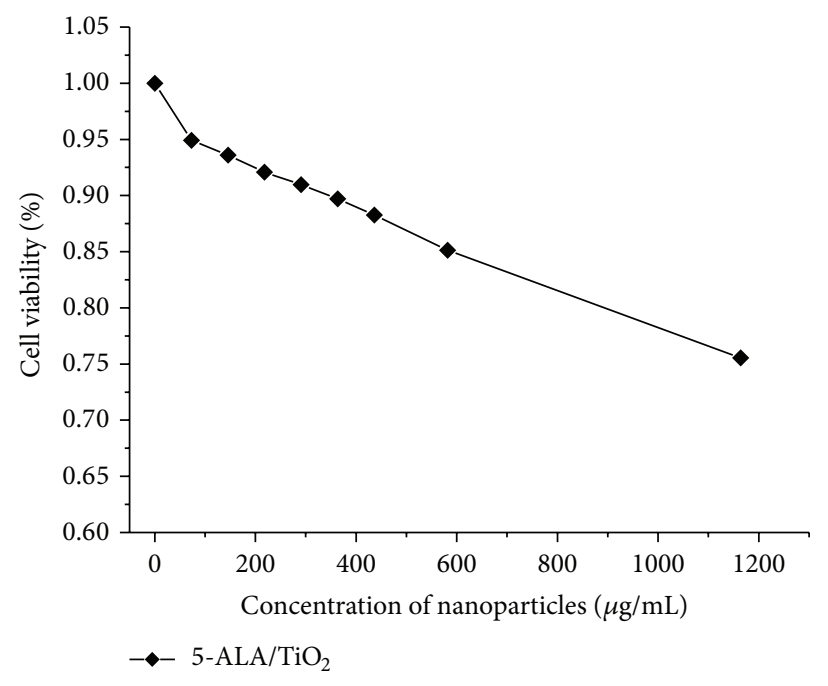

(b)

Figure 5: Effect of (a) $\mathrm{TiO}_{2}$ and $\mathrm{Fe} / \mathrm{TiO}_{2}$ and (b) 5-ALA/TiO 2 of different concentration on $\mathrm{HL} 60$ cell viability.

We learned that the viability of HL60 softly declines with the increase of drug concentration. That said, photosensitive drugs influenced HL60 cells viability without radiation, even though not much. In detail, $\mathrm{TiO}_{2}$ had relatively mild inhibitory effect on HL60 until the concentration went up to $500 \mu \mathrm{g} / \mathrm{mL}$, where cell viability dropped to $90 \%$; the inhibitory effect was more obvious in groups of $\mathrm{Fe} / \mathrm{TiO}_{2}$ and $\mathrm{Fe} / \mathrm{TiO}_{2}(5 \%)$ appeared to have higher toxicity than $\mathrm{Fe} / \mathrm{TiO}_{2}(2 \%)$. Their cell viability dropped to $90 \%$ when the concentration of $\mathrm{Fe} / \mathrm{TiO}_{2}$ reached approximately $200 \mu \mathrm{g} / \mathrm{mL}$. And note that the curves turned sharper at the concentration range over $200 \mu \mathrm{g} / \mathrm{mL}$. From Figure 5(b), we can observe that the curve of $\mathrm{Fe} / \mathrm{TiO}_{2}$ (5\%) dropped slightly faster than the one of $\mathrm{Fe} / \mathrm{TiO}_{2}(2 \%)$. The $5-\mathrm{ALA} / \mathrm{TiO}_{2}$ group revealed that 5-ALA/ $/ \mathrm{TiO}_{2}$ nanoparticles were less toxic to HL60 cells than $\mathrm{Fe} / \mathrm{TiO}_{2}$, but more than pure $\mathrm{TiO}_{2}$. The corresponding cell viability dropped to $90 \%$ when the concentration of 5$\mathrm{ALA} / \mathrm{TiO}_{2}$ reached approximately $360 \mu \mathrm{g} / \mathrm{mL}$.

3.3. Photodynamic Therapy on HL60. HL60 cells in a concentration of $0.5 \times 10^{5} / \mathrm{mL}$ were inoculated into two 96 -well plates marked as A and B. Plate A received light treatment (luminous power $5 \mathrm{~mW} / \mathrm{cm}^{2}$, light dose $18 \mathrm{~J} / \mathrm{cm}^{2}$, wavelength $403 \pm 6 \mathrm{~nm}$, period 1 hour) after 24-hour incubation in dark and then another 24-hour incubation in dark. Plate $\mathrm{B}$, as control group, was incubated in dark for continuous 48 hours in the incubator. According to Figure 5, the final concentration we adopted was $200 \mu \mathrm{g} / \mathrm{mL}$ for $\mathrm{TiO}_{2}, \mathrm{Fe} / \mathrm{TiO}_{2}$ (2\%), and $\mathrm{Fe} / \mathrm{TiO}_{2}(5 \%)$ and $360 \mu \mathrm{g} / \mathrm{mL} 5-\mathrm{ALA} / \mathrm{TiO}_{2}$, for under these concentrations; the viability of HL60 cells was the same $90 \%$ in darkroom experiments. The photocatalytic effect (indicated by $\mathrm{Pe}$ ) was expressed by cell viability, which was calculated as follows:

$$
\mathrm{Pe}=1-\frac{\mathrm{OD}_{\text {treated }}}{\mathrm{OD}_{\text {untreated }}} * 100 \% \text {, }
$$

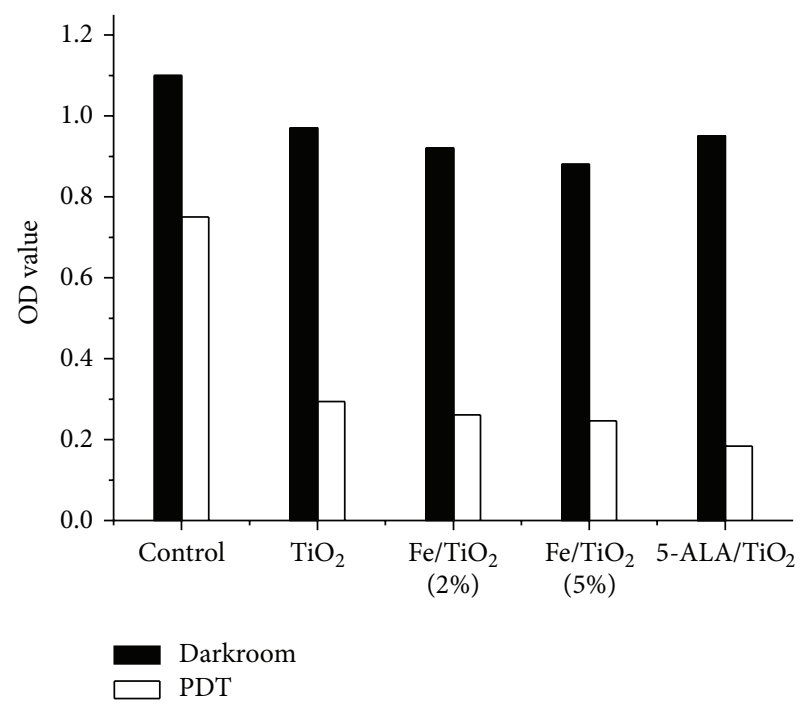

FIGURE 6: Effect of PDT of different nanoparticles on OD value of HL60 cells.

where the $\mathrm{OD}_{\text {treated }}$ and $\mathrm{OD}_{\text {untreated }}$ are the mean absorption values at $490 \mathrm{~nm}$ for the treated and untreated samples, respectively. Overall results were presented in Figure 6.

From Figure 6, we found that the cells viability of control group remained stable relatively. As to PDT group, cell viability dropped remarkably. To state the obvious, cell viability under light treatment of $\mathrm{TiO}_{2}$ decreased greatly to $30.3 \%$; furthermore, the ones of modified $\mathrm{TiO}_{2}$ happened to reach a greater decrease. This evidence revealed that modification of $\mathrm{Fe}$ ion and 5-ALA enhances photocatalytic inactivation effect of $\mathrm{TiO}_{2}$. Specifically, cell viability under 5-ALA/TiO ${ }_{2}^{-}$ PDT dropped to $19.4 \%$ and $\mathrm{Fe} / \mathrm{TiO}_{2}(2 \%)$ and $\mathrm{Fe} / \mathrm{TiO}_{2}$ (5\%) to $28.4 \%$ and $28.0 \%$, respectively. That said, $\mathrm{Fe} / \mathrm{TiO}_{2}$ 


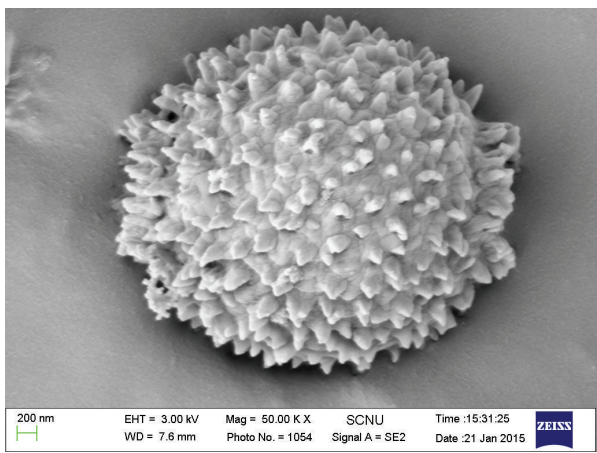

(a)

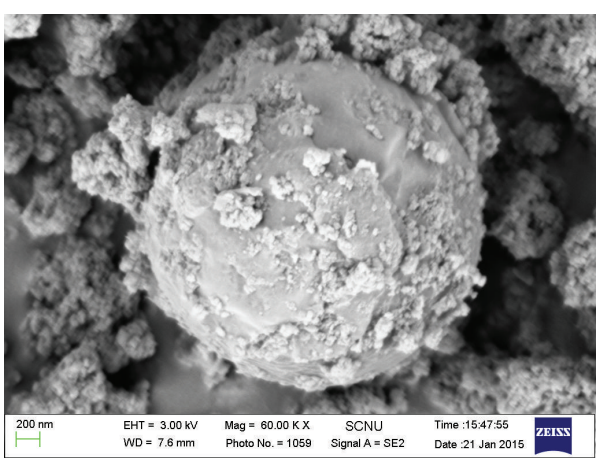

(c)

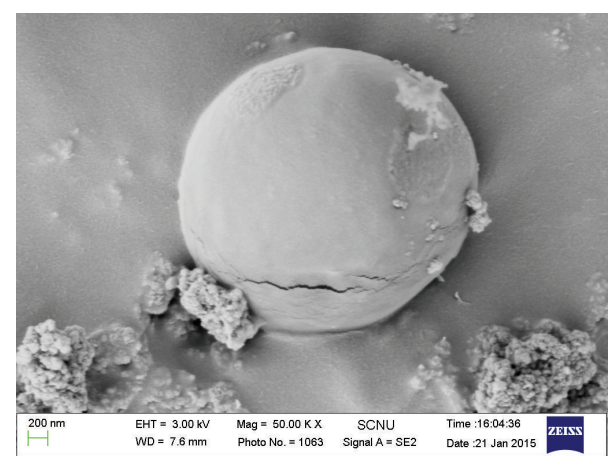

(b)

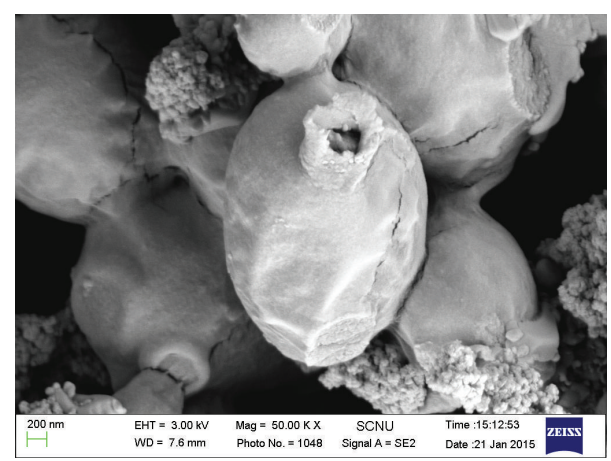

(d)

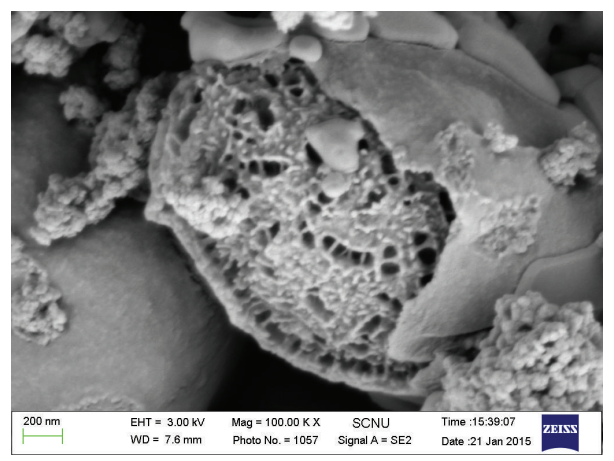

(e)

FIGURE 7: Ultrastructural morphology of HL60 cells: (a) normal cultured cell; (b) cell cultured with Fe/TiO 2 in darkroom; (c) cell cultured with 5-ALA/TiO 2 in darkroom; (d) PDT-treated cell cultured with $\mathrm{Fe} / \mathrm{TiO}_{2}$; (e) $\mathrm{PDT}$-treated cell cultured with 5-ALA/TiO .

nanoparticles did not present obviously higher photocatalytic effect in comparison to pure $\mathrm{TiO}_{2}$ nanoparticles. However, 5-ALA/ $\mathrm{TiO}_{2}$ present promising photocatalytic effect. For the viability of HL60 cells of each darkroom group stayed above $80 \%$, and the one of each radiance group nearly stayed all below $30 \%$; we found that the activation of the modified $\mathrm{TiO}_{2}$ from PDT was the main cause of cell apoptosis.

3.4. Scanning Electron Microscope (SEM) Image of the Treated HL60 Cells. The ultrastructural morphology of HL60 cell, the ultrastructural morphology of HL60 cell cultured with $\mathrm{Fe} / \mathrm{TiO}_{2}$ and 5-ALA/TiO ${ }_{2}$, and the ultrastructural morphology of PDT-treated HL60 cell cultured with 5-ALA/TiO 2 and 5-ALA/TiO 2 were shown in Figures 7(a), 7(b), 7(c), 7(d), and 7(e), respectively. In Figure 7(a), HL60 cell was observed to remain morphologically intact. In Figures $7(b)$ and $7(c)$, we observed plump HL60 cells with smooth surface, attached or covered by nanoparticles. Based on experience, cell viability was slightly influenced in this stage. In Figure $7(d)$, the HL60 cell surface became hollow and deform; breakage of cytomembrane was observed clearly. In Figure 7(e), the same condition emerged in HL60 cell. From it, not only the breakdown of cytomembrane but also the damage of the inner cytoplasm was obviously observed. Damaged cytoplasm was observed to have entirely extruded out from cytomembrane in certain PDT-treated cells.

\section{Conclusion}

In this paper, the modification of $\mathrm{Fe}$ and 5-ALA on $\mathrm{TiO}_{2}$ was explored in experiments. $\mathrm{Fe} / \mathrm{TiO}_{2}(2 \%), \mathrm{Fe} / \mathrm{TiO}_{2}(5 \%)$ were 
synthesized by precipitation method and 5-ALA/TiO 2 was synthesized by ultrasonic method. They were all used as experimental photosensitizer in photodynamic therapy. Xray diffraction was used to verify their anatase phase; and the UV-Vis spectrum indicated that the modification of $\mathrm{TiO}_{2}$ leads to a redshift of absorption spectrum. Our experimental results showed that the modification of $\mathrm{TiO}_{2}$ promotes the absorption in visible light region of $\mathrm{TiO}_{2} \cdot \mathrm{TiO}_{2}$ and modified $\mathrm{TiO}_{2}$ develop nearly no harm to HL60 cells when in darkroom with proper experimental doses but can still result in cell death in high concentration. Our experiment proved that modified $\mathrm{TiO}_{2}$ nanoparticles performed a high photocatalytic effect on HL60 cells than pure $\mathrm{TiO}_{2}$. And among all three kinds of them, 5-ALA/TiO 2 had the greatest inhibitory effect on HL60 cells. Besides, $\mathrm{Fe} / \mathrm{TiO}_{2}$ (5\%) cause a higher inhibitory effect than $\mathrm{Fe} / \mathrm{TiO}_{2}(2 \%)$, indicating that higher proportion of $\mathrm{Fe}^{+}$in modified $\mathrm{TiO}_{2}$ performs better photocatalytic effect in light treatments. Three kinds of nanoparticles, including 5-ALA/TiO 2 in $360 \mu \mathrm{g} / \mathrm{mL}, \mathrm{Fe} / \mathrm{TiO}_{2}(2 \%)$ in $200 \mu \mathrm{g} / \mathrm{mL}$, and $\mathrm{Fe} / \mathrm{TiO}_{2}(5 \%)$ in $200 \mu \mathrm{g} / \mathrm{mL}$, were used in photodynamic therapy on HL60 cells for 1-hour light treatment in a luminous power of $5 \mathrm{~mW} / \mathrm{cm}^{2}$. Cell viability of each independent group was $19.4 \%, 28.4 \%$, and $28.0 \%$ respectively, indicating that $5-\mathrm{ALA} / \mathrm{TiO}_{2}$ nanoparticles had a higher inhibitory effect in the doses which caused the same dark toxicity, yet $\mathrm{Fe} / \mathrm{TiO}_{2}$ nanoparticles did not present obviously higher photocatalytic effect in comparison to pure $\mathrm{TiO}_{2}$ nanoparticles.

Scanning electron microscope was used to observe the ultrastructural morphology of HL60 cells before and after PDT and the images and PDT results together showed that the synthesized nanoparticles cause obvious damage on HL60 through PDT.

\section{Conflict of Interests}

The authors declare that there is no conflict of interests regarding the publication of this paper.

\section{Acknowledgments}

This work has been financially supported by the National Natural Science Foundation of China (61072029) and Science and Technology Planning Project of Guangzhou City (2014J4100049).

\section{References}

[1] Q. X. Zhou, Z. Fang, J. Li, and M. Wang, "Applications of $\mathrm{TiO}_{2}$ nanotube arrays in environmental and energy fields: a review," Microporous and Mesoporous Materials, vol. 202, pp. 22-35, 2015.

[2] S. T. Hussain and A. Siddiqa, "Iron and chromium doped titanium dioxide nanotubes for the degradation of environmental and industrial pollutants," International Journal of Environmental Science and Technology, vol. 8, no. 2, pp. 351-362, 2011.

[3] M. Behpour, S. M. Ghoreishi, and F. S. Razavi, "Photocatalytic aactivity of $\mathrm{TiO}_{2} / \mathrm{Ag}$ nanoparticle on degradation of water pollutions," Digest Journal of Nanomaterials and Biostructures, vol. 5, no. 2, pp. 467-475, 2010.

[4] C. Wang, H. Liu, and Y. Qu, “ $\mathrm{TiO}_{2}$-based photocatalytic process for purification of polluted water: bridging fundamentals to applications," Journal of Nanomaterials, vol. 2013, Article ID 319637, 14 pages, 2013.

[5] T. Zubkoy, D. Stahl, T. L. Thompson, D. Panayotov, O. Diwald, and J. T. Yates Jr., "Ultraviolet light-induced hydrophilicity effect on $\mathrm{TiO}_{2}(110)(1 \times 1)$. Dominant role of the photooxidation of adsorbed hydrocarbons causing wetting by water droplets," Journal of Physical Chemistry B, vol. 109, no. 32, pp. 15454-15462, 2005.

[6] J. Wang, Y. Guo, B. Liu et al., "Detection and analysis of reactive oxygen species (ROS) generated by nano-sized $\mathrm{TiO}_{2}$ powder under ultrasonic irradiation and application in sonocatalytic degradation of organic dyes," Ultrasonics Sonochemistry, vol. 18, no. 1, pp. 177-183, 2011.

[7] N. Shimizu, C. Ogino, M. F. Dadjour, K. Ninomiya, A. Fujihira, and K. Sakiyama, "Sonocatalytic facilitation of hydroxyl radical generation in the presence of $\mathrm{TiO}_{2}$," Ultrasonics Sonochemistry, vol. 15, no. 6, pp. 988-994, 2008.

[8] Y. Chihara, K. Fujimoto, H. Kondo et al., "Anti-tumor effects of liposome-encapsulated titanium dioxide in nude mice," Pathobiology, vol. 74, no. 6, pp. 353-358, 2007.

[9] J. Yu, L. Qi, and M. Jaroniec, "Hydrogen production by photocatalytic water splitting over $\mathrm{Pt} / \mathrm{TiO}_{2}$ nanosheets with exposed (001) facets," Journal of Physical Chemistry C, vol. 114, no. 30, pp. 13118-13125, 2010.

[10] C. M. Sayes, R. Wahi, P. A. Kurian et al., "Correlating nanoscale titania structure with toxicity: a cytotoxicity and inflammatory response study with human dermal fibroblasts and human lung epithelial cells," Toxicological Sciences, vol. 92, no. 1, pp. 174-185, 2006.

[11] J. Xu, Y. Sun, J. Huang et al., "Photokilling cancer cells using highly cell-specific antibody- $\mathrm{TiO}_{2}$ bioconjugates and electroporation," Bioelectrochemistry, vol. 71, no. 2, pp. 217-222, 2007.

[12] T. López, M. Alvarez, R. D. González et al., "Synthesis, characterization and in vitro cytotoxicity of $\mathrm{Pt}-\mathrm{TiO}_{2}$ nanoparticles," Adsorption, vol. 17, no. 3, pp. 573-581, 2011.

[13] T. Lopez, E. Ortiz, M. Alvarez et al., "Study of the stabilization of zinc phthalocyanine in sol-gel $\mathrm{TiO}_{2}$ for photodynamic therapy applications," Nanomedicine: Nanotechnology, Biology, and Medicine, vol. 6, no. 6, pp. 777-785, 2010.

[14] S. Yamaguchi, H. Kobayashi, T. Narita et al., "Novel photodynamic therapy using water-dispersed $\mathrm{TiO}_{2}$-polyethylene glycol compound: Evaluation of antitumor effect on glioma cells and spheroids in vitro," Photochemistry and Photobiology, vol. 86, no. 4, pp. 964-971, 2010.

[15] Z. Li, X. Pan, T. Wang, P.-N. Wang, J.-Y. Chen, and L. Mi, “Comparison of the killing effects between nitrogen-doped and pure $\mathrm{TiO}_{2}$ on HeLa cells with visible light irradiation," Nanoscale Research Letters, vol. 8, no. 1, pp. 1-7, 2013.

[16] W. Wang, Q. Shang, W. Zheng et al., "A novel near-infrared antibacterial material depending on the upconverting property of $\mathrm{Er}^{3+}-\mathrm{Yb}^{3+}-\mathrm{Fe}^{3+}$ tridoped $\mathrm{TiO}_{2}$ nanopowder," Journal of Physical Chemistry C, vol. 114, no. 32, pp. 13663-13669, 2010.

[17] Z. Li, L. Mi, P.-N. Wang, and J.-Y. Chen, "Study on the visible-light-induced photokilling effect of nitrogen-doped $\mathrm{TiO}_{2}$ nanoparticles on cancer cells," Nanoscale Research Letters, vol. 6, no. 1, pp. 1-7, 2011.

[18] J. Xu, Y. Sun, Y. M. Zhao, J. J. Huang, C. M. Chen, and Z. Y. Jiang, "Photocatalytic inactivation effect of gold-doped $\mathrm{TiO}_{2}$ 
$\left(\mathrm{Au} / \mathrm{TiO}_{2}\right)$ nanocomposites on human colon carcinoma LoVo cells," International Journal of Photoenergy, vol. 2007, Article ID 97308, 7 pages, 2007.

[19] K. Huang, L. Chen, J. Deng, and J. Xiong, "Enhanced visiblelight photocatalytic performance of nanosized anatase $\mathrm{TiO}_{2}$ doped with CdS quantum dots for cancer-cell treatment," Journal of Nanomaterials, vol. 2012, Article ID 720491, 12 pages, 2012.

[20] K. Huang, L. Chen, J. Xiong, and M. Liao, "Preparation and characterization of visible-light-activated $\mathrm{Fe}-\mathrm{N} \mathrm{Co}$-doped $\mathrm{TiO}_{2}$ and its photocatalytic inactivation effect on leukemia tumors," International Journal of Photoenergy, vol. 2012, Article ID 631435, 9 pages, 2012.

[21] J. W. Xiong, H. Xiao, L. Chen, J. M. Wu, and Z. X. Zhang, "Research on different detection conditions between MTT and CCK-8," Acta Laser Biology Sinica, vol. 16, no. 5, pp. 526-531, 2007.

[22] K. Tanaka, M. F. V. Capule, and T. Hisanaga, "Effect of crystallinity of $\mathrm{TiO}_{2}$ on its photocatalytic action," Chemical Physics Letters, vol. 187, no. 1-2, pp. 73-76, 1991.

[23] R. I. Bickley, T. Gonzalez-Carreno, J. S. Lees, L. Palmisano, and R. J. D. Tilley, "A structural investigation of titanium dioxide photocatalysts," Journal of Solid State Chemistry, vol. 92, no. 1, pp. 178-190, 1991. 

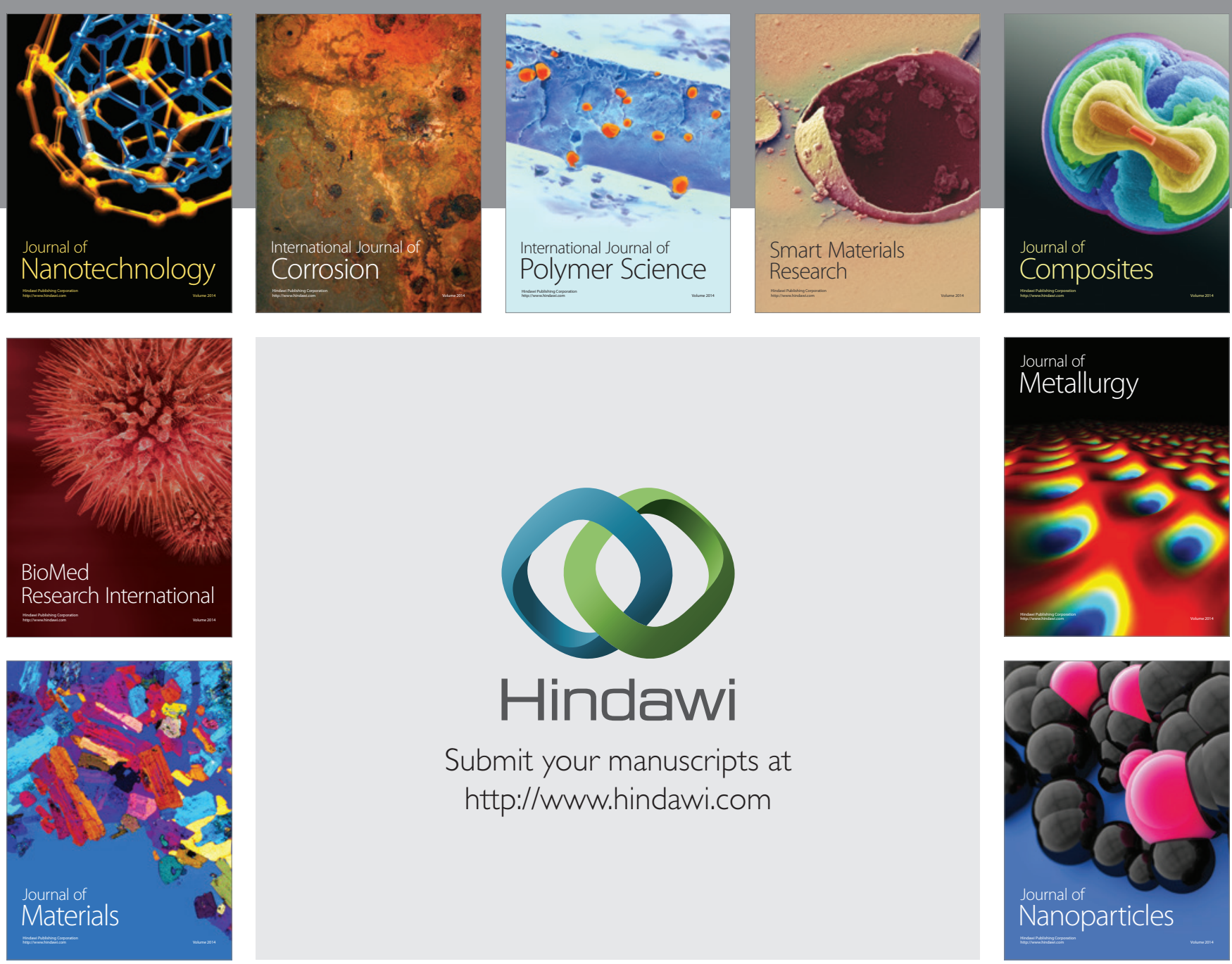

Submit your manuscripts at http://www.hindawi.com
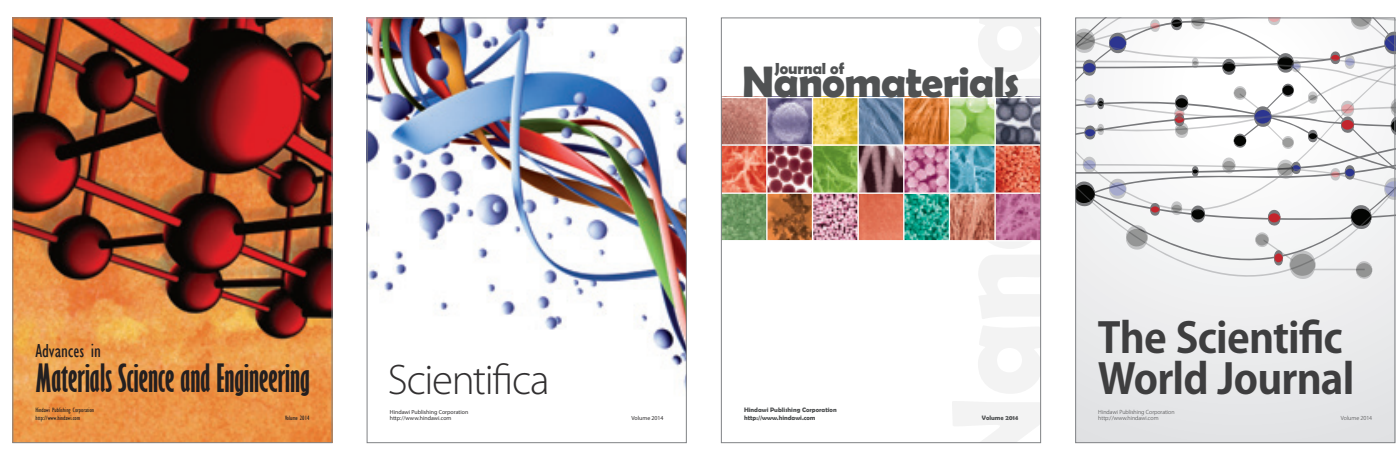

\section{The Scientific World Journal}
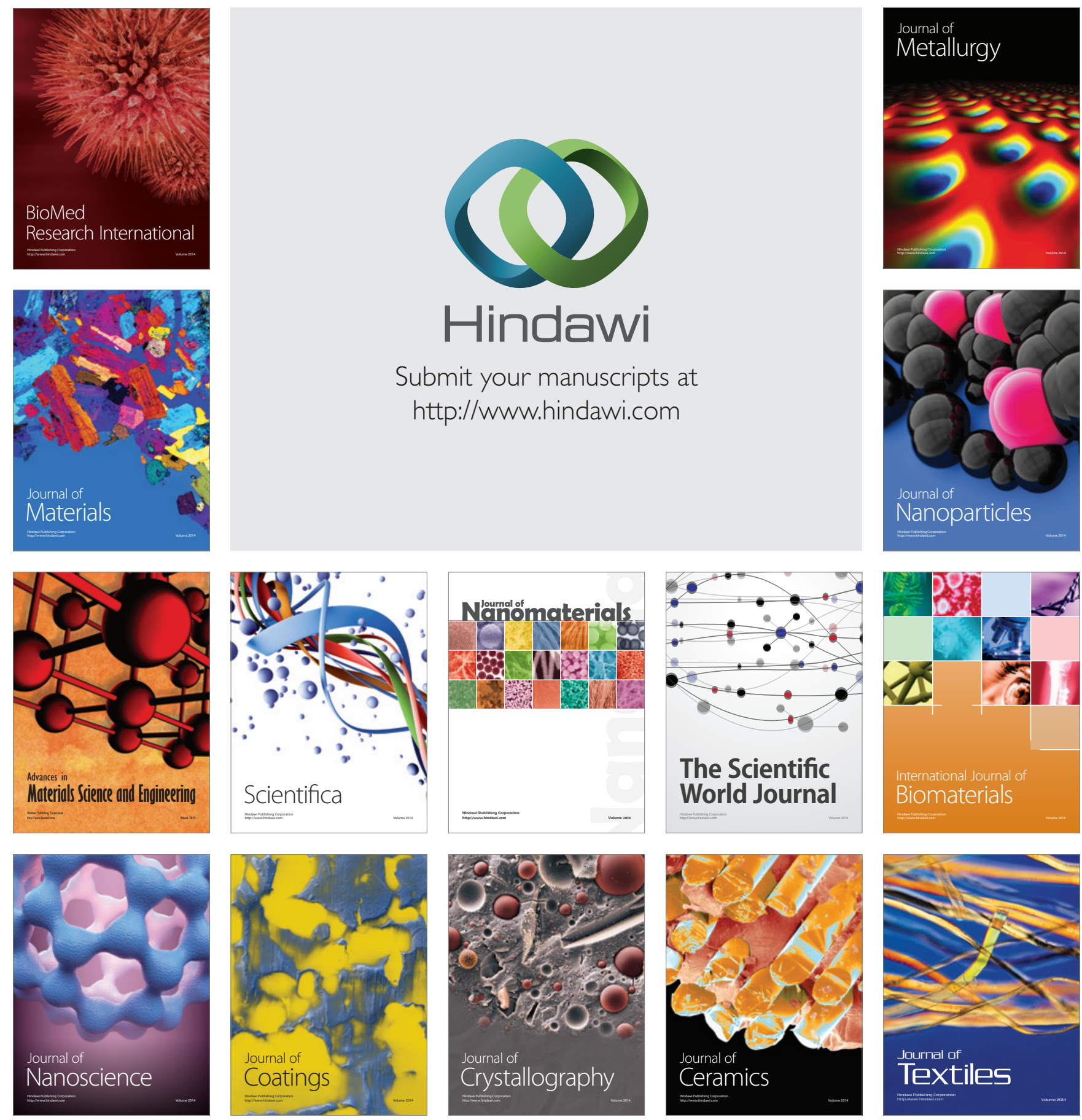